\title{
Le Yak, l'orge et le sel. Une société de montagne en milieu semi-aride Himalayen
}

Corneille Jest

\section{(2) OpenEdition \\ Journals}

Édition électronique

URL : https://journals.openedition.org/tc/902

DOI : $10.4000 /$ tc. 902

ISSN : 1952-420X

Éditeur

Éditions de l'EHESS

Édition imprimée

Date de publication : 1 septembre 1986

ISSN : 0248-6016

Référence électronique

Corneille Jest, « Le Yak, l'orge et le sel. Une société de montagne en milieu semi-aride Himalayen », Techniques \& Culture [En ligne], 7 | 1986, mis en ligne le 23 janvier 2006, consulté le 29 septembre 2022. URL : http://journals.openedition.org/tc/902 ; DOI : https://doi.org/10.4000/tc.902

Ce document a été généré automatiquement le 29 septembre 2022

Tous droits réservés 
Le Yak, l'orge et le sel. Une société de montagne en milieu semi-aride Himalayen

Corneille Jest 